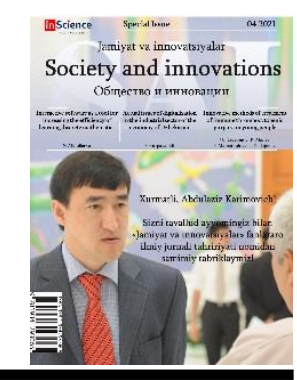

\title{
Types of tourism and translation of some words related to tourism
}

\author{
Bobur TOGAEV1 ${ }^{1}$ Khalifa PALUANOVA ${ }^{2}$ \\ Termez State University \\ Uzbekistan State University of World Languages
}

\begin{tabular}{l} 
ARTICLE INFO \\
\hline Article history: \\
Received March 2021 \\
Received in revised form \\
20 March 2021 \\
Accepted 15 April 2021 \\
Available online \\
20 May 2021
\end{tabular}

ABSTRACT

This article discusses the importance of tourism and the fields of tourism, as well as the translation of words related to tourism in English and Uzbek.

2181-1415/@ 2021 in Science LLC.

This is an open access article under the Attribution 4.0 International (CC BY 4.0) license (https://creativecommons.org/licenses/by/4.0/deed.ru)

\footnotetext{
Keywords:

travel,

tourist,

tourism classification,

inbound tourism,

sports tourism.
}

\section{Turizmning turlari va turizmga oid ayrim so'zlarning tarjimasi}

\author{
Kalit so'zlar: \\ sayohat, \\ sayohatchi, \\ turizm tasnifi, \\ ichki turizm, \\ sport turizmi.
}

\section{ANNOTATSIYA}

Ushbu maqola turizmning ahamiyati va turizm sohalari haqida, turizmga oid so'zlarning ingliz va o'zbek tillarida tarjimasi haqida so'z yuritadi.

\section{Виды туризма и перевод некоторых слов, относящихся к туризму}

\footnotetext{
Ключевые слова:

путешествие,

турист,

классификация туризма,

внутренний туризм,

спортивный туризм.
}

\begin{abstract}
АННОТАЦИЯ
В этой статье обсуждается важность туризма и сфер туризма, а также перевод слов, связанных с туризмом на английский и узбекском языках.
\end{abstract}

\footnotetext{
${ }^{1}$ Master, Termez State University. Termez, Uzbekistan.

2 Doctor of Philological Sciences, Uzbekistan State University of World Languages. Tashkent, Uzbekistan.
} 
The word "tourism" (tourisme, from tour) in translation from French means "walk", "trip", "travel". "Tourism" - the business of providing services such as transport, places to stay, or entertainment for people who are on holiday [4].

The word tourist was used in 1772 and tourism in 1811. It is formed from the word tour, which is derived from Old English turian, from Old French torner, from Latin tornare; "to turn on a lathe", which is itself from Ancient Greek tornos (

Tourism is a journey made by a person in his free time from his main work for health, educational, professional, business, sports, religious and other purposes. This is one of the types of outdoor activities, the best way to escape from the hustle and bustle, to see new and interesting, to gain positive emotions. Tourism provides an opportunity to get acquainted with the culture of other countries and regions, satisfies the curiosity of a person, enriches him spiritually, heals physically, promotes personal development. It allows you to combine relaxation with learning new things.

Tourist travel involves only a temporary departure of a person outside his usual environment, without conducting paid activities at the place of stay, which excludes from the category of tourist's people who are professionally or forced to travel (diplomats and consular officers, military personnel, emigrants, refugees, nomads, etc.).

Tourism resources (natural, cultural, historical) are the basis for the development of tourism. The key figure in tourism is the tourist. He acts as a consumer of tourist product or services (tour), for its quality service, the tourism industry is formed and operates. Significance for the economy. Tourism is not only travel and recreation, but also an important area of the economy. The tourism industry covers enterprises of various industries, from the products and services of which the tour operator creates an attractive tourist product for the consumer. The tourism industry contributes to the flow of financial resources into the country. It not only generates income for travel companies, but also provides tax revenues, increases the demand for food and a variety of services, thereby stimulating the development of related industries (transport, hospitality, communications, trade and public catering, souvenir production, etc.). Tourist service is a source of income for the local population. This type of activity does not require large start-up investments, is distinguished by a high level of profitability and a relatively short payback period for capital investments. The development of tourism contributes to the creation of new jobs and provides employment for the population (foreign experience shows that it takes up to people).

Socio-cultural significance. The development of tourism improves the system of social and cultural services for the population, increases resources for the modernization of the relevant infrastructure, and improves the quality of life.

Political significance. Tourism raises the country's prestige, its authority in the world community and among ordinary citizens. It strengthens interregional and international friendly ties, develops public diplomacy, and stabilizes relations between regions and states. The level of tourism development is a kind of indicator of the state of society, its material wealth and spiritual health.

\section{Development conditions}

World experience shows that the following conditions are necessary for the dynamic development of tourism: 
- a stable socio-economic situation (in the world as a whole, in a particular country and a specific region);

- absence of administrative and bureaucratic barriers when traveling across borders and during a guest stay;

- attractive recreational resources (natural-climatic and cultural-historical);

- developed tourism infrastructure and qualified personnel;

- a high level of service, ensuring a comfortable stay, hospitality, culture and professionalism of the staff;

- comfortable and safe transport, reliable communication;

- freedom of movement and guarantees of the rights of travelers, ensuring their safety;

- high responsibility of tourist organizations and their structural units for specific tours;

- positive tourist image of the territory, high reputation of firms and companies serving tourists.

\section{Key Features}

There are several main features of tourist activity.

The first and most significant is that, unlike the material industries, the tourism industry does not export a product, but an experience. To better reveal this feature, we will give an example. You can export 1 ton of oil, say, for 100-150 dollars. At the same time, the sold oil will go outside the country, and its reserves in the earth's interior will no longer be restored. A room in a first-class hotel can also bring you $\$ 100-150$, but every day! It can give tens of thousands of dollars a year, eliminating the need to export seven or eight railroad oil tanks. The same applies to the export of other non-renewable natural resources. The tourist, however, does not take anything from the country, except for impressions (virtual product), but leaves completely material - money.

This feature is extremely important for modern Russia, which exports nonrenewable resources (oil, gas, metals) and at the same time favorable conditions for the development of tourism.

The second feature is associated with the specificity of products and services, the inability to move them to the consumer. The tourist, and not the manufacturer or seller, must move to the place of their production. This specificity is due to objective reasons. After all, it is impossible to move Baikal, Balaton or the Alps to a tourist. Hence the third feature follows. It consists in the fact that the products of the tourism industry are a set of services that can be tested only at the time of consumption. In this regard, the successful sale of a tourism product presupposes a particularly trusting relationship between customers and sellers. Therefore, the high reputation of tour operators and travel agents, hotels and airlines is extremely important here.

\section{Classification}

The classification of modern tourist activity is carried out according to its most essential features, presented in the table.

Form of organization It is necessary to give brief explanations to this table with characteristics main types of tourism. 


\section{Tourism classification}

\begin{tabular}{|c|c|}
\hline Classification attribute & Type of tourism \\
\hline \multirow{2}{*}{ Travel geography } & Interior \\
\hline & International (foreign) \\
\hline \multirow{3}{*}{ The direction of the tourist flow } & Entry \\
\hline & Outbound \\
\hline & Interior \\
\hline \multirow{12}{*}{ Purpose of travel } & Recreational (wellness) \\
\hline & Cognitive (excursion) \\
\hline & Cultural \\
\hline & Scientific and educational \\
\hline & Professional and business \\
\hline & Sports \\
\hline & Ecological \\
\hline & Adventure (extreme) \\
\hline & Shopping tours \\
\hline & Religious (pilgrimage) \\
\hline & Nostalgic \\
\hline & Exotic \\
\hline \multirow{11}{*}{ Source of financing } & Commercial \\
\hline & Social \\
\hline & Pedestrian \\
\hline & Equestrian \\
\hline & Bicycle \\
\hline & Autotourism \\
\hline & Railway \\
\hline & Nautical \\
\hline & River \\
\hline & Aviation \\
\hline & Mixed \\
\hline \multirow{3}{*}{ Number of participants } & Individual \\
\hline & Family \\
\hline & Group \\
\hline \multirow{2}{*}{ Form of organization } & Organized \\
\hline & Unorganized (amateur, "wild" \\
\hline
\end{tabular}

Domestic tourism - travel of citizens within the country, without crossing the state border (and without performing paid professional activities in the place of temporary stay). This type of tourism especially popular in the USA. In our country, it also accounts for about $80 \%$ of tourist trips.

The significance of domestic tourism is still invisible due to the lack of commonly accepted and used definitions of domestic travel, another reason is that the available domestic tourism data is mostly in the form of number of trips to destinations beyond a certain minimum distance from the normal place of residence [5].

International (foreign) tourism - travel outside the country of permanent residence for tourist purposes. Foreign tourists include all temporary visitors who have arrived in a given country for at least 24 hours (except for paid professional activities in the country being visited). A foreign tourist becomes, as it were, a temporary visitor to another country. After the unification of Europe and the creation of the European Union, the 
convergence of domestic and international tourism began, due to the simplification of customs formalities (Schengen Agreement).

\begin{tabular}{|c|c|}
\hline \multicolumn{2}{|c|}{ Holiday activities and equipment } \\
\hline Abseiling & Alpinism \\
\hline Golf & Golf \\
\hline bungee jumping & Arqon bog'lab balandlikdan sakrash \\
\hline Clubbing & Klubda vaqt o'tkazmoq \\
\hline Cycling & Velosipedda harakatlanish \\
\hline Eating out & Ko'chadan ovqatlanish \\
\hline Jeep safari & Jip safari (cho'l, tog'li hududda mashinada sayohat) \\
\hline Scuba diving & Akvalang yordamida suv ostida suzish \\
\hline Fishing / Deep-sea fishing & Baliq ovi / Dengizdan baliq ovlash \\
\hline Go-karting & Poyga \\
\hline Hang-gliding & Deltaplanda uchish \\
\hline Horse riding & Ot minish \\
\hline Inter-railing & Poyezdda sayohat \\
\hline Parachuting & Parashyutda sakrash \\
\hline Sailing & Dengiz sayohati \\
\hline Surfing & Syorfing \\
\hline Parasailing & Paraseyling (suv ustida parashut bilan uchish) \\
\hline Rock or mountain climbing & Qoya yoki toqqa chiqish \\
\hline Sightseeing & Diqqatga sazovor joylarni tomosha qilish \\
\hline Swimming & Suzish \\
\hline Skiing & Chang'i \\
\hline Tennis & Tennis \\
\hline Snowboarding & Snoubord (qorda uchmoq) \\
\hline Sunbathing & Quyoshda toblanmoq \\
\hline Volleyball & Voleybol \\
\hline Walking / Hiking & Yurish \\
\hline Water skiing & Suv chang'isi \\
\hline Windsurfing & Shamol syorfingi \\
\hline
\end{tabular}

Inbound tourism - travel for tourist purposes within the country of persons who do not reside in it permanently. The reception of foreign tourists in the country is a kind of export of services (this is how the World Tourism Organization defines inbound tourism, since the profit from it goes to the host country in foreign currency).

Inbound tourism brings both benefits and costs to a destination country. For policy reasons, it is necessary that the net benefits of inbound tourism be accurately assessed for different countries [6].

Outbound tourism - travel of citizens permanently residing in one country abroad for tourist purposes.

Recreational (health) tourism - travel for rest and treatment. It can be subdivided into beach (visiting the sea coast, especially in winter) and sanatorium-resort, characterized by a longer duration (the usual duration of a treatment tour is 21-28 days, which is much longer than for other types of tourism). Although health-improving recreation is of a purely individual nature, recreational tourism is the most widespread type of tourism. It can include entertainment and entertainment programs (theater and 
film festivals), hobby classes (hunting, fishing, musical and artistic creativity), ethnic trips (related to the study of the national culture of the host country), etc.

Health tourism is an opportunity of sustainable development that can be declined along several directories, taking advantage in Europe of the cross-border availability of services for health. Sharing data and allowing data retrieval for specific citizens is an important enabling factor to the set-up of personalized offer for health to strengthen the tourist offer [7].

Cognitive (excursion) tourism - travel or excursions with cognitive and broadening horizons. Automobile tourism is a kind of educational trips. Compared to traveling on other types of vehicles travel by car and buses provide tourists with much more educational opportunities.

Cultural tourism involves visiting places of cultural and historical heritage and concentration of cultural monuments, as well as places where cultural and entertainment events are held. It can be subdivided into cultural and educational, cultural and entertainment, ethnic, etc. This type of tourism is the best way to get acquainted with world culture. After all, every country and every nation has its own unique cultural heritage, which is the heritage of all mankind. Acquaintance with the history and culture of other countries enriches, makes life more eventful and interesting. The cultural heritage of the people consists of the works of artists, architects, musicians, writers, scientists, masters of folk art. Culture covers both tangible and intangible works, customs, language. The objects of tourist activity can be museums, theaters, nature reserves, places of important historical events, monuments of history and architecture, festivals and symposia, objects of religious worship, libraries, etc.

Scientific and educational tourism is a relatively new type of international tourism, involving travel for the purpose of scientific work, training or advanced training. Specialized types of scientific tourism are paleontological, archaeological, limnological, etc. In addition, scientific tourism can include participation in research expeditions, scientific symposia and conferences. When it comes to educational tourism, language learning trips are the most popular here, especially to the UK and other English-speaking countries.

Professional - business tourism involves business trips related to the performance of professional duties (participation in festivals, forums, conferences, symposia, fairs, etc.). For this, large congress centers are being created with meeting rooms and business meetings to accommodate visitors. Business travelers spend significantly more money in the place of stay than ordinary tourists. Therefore, many states strive to host major international events. The big advantage of this type of tourism is the possibility of organizing it during the low season.

Sports tourism - associated with travel to various sports events. The popularity of this type of tourism is constantly growing. It allows you to engage in selected sports (skiing, swimming, sport fishing and hunting, etc.), as well as "root" for your favorite team, personally attending major sporting events. This is all the more important because, in according to the recommendations of the World Tourism Organization, tourism and recreation, along with physical education and sports, should be considered inseparably and interconnected. 


\begin{tabular}{|c|c|}
\hline \multicolumn{2}{|c|}{ Holiday activities and equipment } \\
\hline Abseiling & Alpinizm \\
\hline Golf & Golf \\
\hline Bungee jumping & Arqon bog'lab balandlikdan sakrash \\
\hline Clubbing & Klubda vaqt o'tkazmoq \\
\hline Cycling & Velosipedda harakatlanish \\
\hline Eating out & Ko'chadan ovqatlanish \\
\hline Jeep safari & Jip safari (cho'l, tog'li hududda mashinada sayohat) \\
\hline Scuba diving & Akvalang yordamida suv ostida suzish \\
\hline Fishing / Deep-sea fishing & Baliq ovi / Dengizdan baliq ovlash \\
\hline Go-karting & Poyga \\
\hline Hang-gliding & Deltaplanda uchish \\
\hline Horse riding & Ot minish \\
\hline Inter-railing & Poyezdda sayohat \\
\hline Parachuting & Parashyutda sakrash \\
\hline Sailing & Dengiz sayohati \\
\hline Surfing & Syorfing \\
\hline Parasailing & Paraseyling (suv ustida parashut bilan uchish) \\
\hline Rock or mountain climbing & Qoya yoki toqqa chiqish \\
\hline Sightseeing & Diqqatga sazovor joylarni tomosha qilish \\
\hline Swimming & Suzish \\
\hline Skiing & Chang'i \\
\hline Tennis & Tennis \\
\hline Snowboarding & Snoubord (qorda uchmoq) \\
\hline Sunbathing & Quyoshda toblanmoq \\
\hline Volleyball & Voleybol \\
\hline Walking / hiking & Yurish \\
\hline Water skiing & Suv chang'isi \\
\hline Windsurfing & Shamol syorfingi \\
\hline
\end{tabular}

Ecological tourism (ecotourism) - involves the use of natural resources (natural monuments and natural attractions) to organize a wide range of travel - from small educational tours for schoolchildren to regular tourist programs in national parks and reserves. It shows the importance of environmental protection. The profit received by travel agencies can be partially directed to environmental protection measures. This type of tourism stimulates the careful use of valuable and fragile natural resources. Adventure (extreme) tourism is associated with great physical exertion and emotional stress, with risk and adventure. It is a peculiar way of resting in especially attractive and untouched by economic development places, engaging in unusual and risky activities. Adventure tours belong to the category of elite recreation. Such trips are expensive, however, the demand for them is growing steadily. They are very popular in the West. The geography of adventure tours is extensive; the topics are varied. As a rule, these are group tours ("royal hunting", elk fishing, "search for pirate treasures", safari tours, sea travel, river rafting, sailing, scuba diving (diving), hiking, etc.). Qualified instructors are needed to ensure the safety of such tours. Shopping tours are typical for developing countries. In Russia and the CIS, the maximum of shopping tours occurred in the early 1990s, a period of economic crisis and empty store shelves. In those years, many citizens traveled abroad and purchased consumer goods there (shoes, knitwear, etc. - in Turkey, Poland, China, and other countries). For example, in Turkey, Russian "shuttle traders" annually bought goods worth \$ 8-10 billion. It is no coincidence that the governments of these countries do their 
best to support shopping tourism from Russia, simplifying customs formalities as much as possible. Religious (pilgrimage) tourism aims to visit holy places, centers of concentration of church monuments and relics. It involves travel to participate in important religious ceremonies, educational tours to get acquainted with religious monuments, history and culture of various religions, as well as scientific trips of specialists related to religious issues. This type of tourism requires qualified personnel so that they can not only show architectural and historical sights, but also be familiar with spiritual and religious values.

Nostalgic tourism - is based on the need for people to visit far-away relatives and friends, as well as their places of birth. It occupies an important place in international tourist exchanges.

Exotic tourism - has begun to develop recently. Tours have appeared that are striking in their uniqueness. For example, some companies offer space cruises and even flights to the moon. There are companies organizing a cruise to Antarctica and the North Pole. Other equally unexpected travels are possible.

Social tourism - is a type of tourism subsidized from funds allocated for social needs. The purpose of this type of tourism is not to make a profit, but to create the creation of travel conditions for poorly protected segments of the population (students, pensioners, disabled people, war and labor veterans, rural workers, etc.). Social tourism was developed in the USSR. It accounted for almost $60 \%$ of organized domestic tourism and $50 \%$ of outbound international tourism. Inexpensive hotels were built, as well as non-category accommodation facilities (recreation centers, children's camps, etc.), inexpensive food was organized (based on the size of the living wage). In modern conditions, it is possible to provide benefits to tour operators implementing social programs, with the receipt of the status of "social tourism enterprise", etc.

Organized tourism - travel (individual or group) organized by a travel agency, when tourists acquire the right to a tour by purchasing a travel package. Unorganized (amateur, "wild") tourism - travels made by tourists on their own. This type of tourism is the opposite in form of the organized one and is carried out on an amateur, amateur basis, without the purchase of vouchers. It was also widely developed in the USSR. It accounted for $80 \%$ of the total tourist flow.

\section{General concepts}

In conclusion, it is worth presenting a list of the most important concepts that characterize the tourism industry. Tourist resources - natural, historical, socio-cultural and other objects of interest to tourists (including potential ones). Typically, tourism resources are used for display purposes. They are designed to satisfy the curiosity and spiritual needs of a person, give a boost of vigor, improve the emotional state and restore physical strength. The quality of resources is determined by their uniqueness, primordiality and originality, the degree of their positive impact on the physical and mental health of a person. Certain tourist resources attract specific tourists, their appearance and condition largely determine the use value of tours and tourism products in general. Tourism resources are the backbone and integral element of tourism infrastructure.

Tour - a set of services (transportation, accommodation, meals, excursions) provided to the tourist, depending on the purpose of the trip. Abroad, the standard range of services provided to tourists is called a peking tour. The most popular Peking tours are in European countries, where they account for $20-40 \%$ of the total number of trips. They 
include accommodation, meals, excursion services, transportation, household, sports and health and insurance services. At the request of the client, travel agencies can form special tours, according to individual orders, with a wide range of additional services. Such tours are called exclusive tours.

A tourist is a person who travels and visits places outside his usual environment, where there are tourist resources that attract him.

The tourist differs from other travelers (diplomats, emigrants, foreign workers, refugees, nomads, etc.) in the purpose, duration and nature of his trip. He only temporarily visits the country or territory, without engaging in paid activities in the place of residence. As a rule, travel is carried out for recreational, educational, professional and business, sports, religious and other purposes. The duration of the trip can vary from one overnight stay to 6 months (according to international standards - up to 12 months). The tourist is a key element of the tourism business, the consumer of the tourism product. An organized body of tourists is the object of the tourism industry.

Tourist product (tourist product) - the right to a tour intended for sale to a tourist. The tourist product includes the entire set of consumer values consumed by the tourist (the tour itself, tourist and excursion services, special tourist equipment, etc.). Like any product, a tourist product must be of high quality and be in demand (primarily among foreign tourists), otherwise it will not be sold. A quality tourist product must contain at least three components: unique tourist resources; infrastructure elements (implemented technical, utilities, household and other amenities); high culture of service (including language). Such a tourist product captivates the tourist with educational and entertainment opportunities and services, the wealth and variety of attractions. Promotion of a tourist product involves a set of measures aimed at its implementation (organization of advertising, participation in exhibitions and fairs, the creation of information centers for the sale of tours, the publication of catalogs and booklets, etc.). focused on a specific consumer, on his wishes, tastes and capabilities.

Work on the formation and promotion of the tourist product is carried out mainly by tour operators and travel agents.

Tour operator is a tourist enterprise (organization, company), which is engaged in the production delivery of a tourist product and its sale to the consumer through the agent network.

The tour operator is the main organizer in the tourism market. It packs up the tourist opportunities of the territory and various services (transport, accommodation, food, entertainment, etc.) into a single tourist product. Essentially, it loads businesses in the tourism industry (hotels, restaurants, museums, national parks, etc.), connects the manufacturer of tourist services with the consumer (includes a particular museum in the tour, chooses the most suitable hotels, restaurants, shows, etc.).

Travel agent is an intermediary company that sells a tourism product (offered by a tour operator) in the tourism market. This is done by purchasing the tours developed by the tour operator, issuing vouchers for these tours, and selling them to the consumer. For a travel agent, the main thing is to find a client and sell a ticket. For this he receives a commission. The network of travel agents is a retail network of travel products. In relation to the tour operator, the travel agent takes a subordinate place. Being a travel agent is less of a hassle. Unlike a tour operator, he risks less. It does not shape the tour. He does not need to book hotels, make an advance payment, arrange insurance, think over dates, do a lot of work with carriers, conduct advertising campaigns, etc. 
Travel agency activities - activities to promote and sell a tourist product. Travel agency activities - tour operator and travel agency activities, as well as other activities for the organization of travel and development tourism.

Tourist voucher is a document confirming the fact of transfer of a tourist product. A tourist service is the result of the activities of an enterprise serving the tourism sector, to meet the needs of tourists within a specific trip (tour).

From the whole range of services offered, tourists choose the most interesting and relatively inexpensive ones. In order for the price-quality ratio to be optimal and acceptable for tourists, a high attractiveness of tourist resources, a well-developed infrastructure, and an adequate quality of service are required.

\section{REFERENCES:}

1. William F. Theobald. Global Tourism, - Butterworth-Heinemann 2004.

2. Richard Sharpley. Tourism and development: concepts and issues, - Multilingual Matters, 2002.

3. John Swarbrooke, Susan Horner. Business travel and tourism, - ButterworthHeinemann, 2001.

4. https://dictionary.cambridge.org/ru/.

5. https://www.researchgate.net/publication/259643262_Improving_the_Contrib ution_of_Domestic_Tourism_to_the_Economy_of_Jordan.

6. https://www.researchgate.net/publication/223758493_Assessing_the_Benefits _and_Costs_of_Inbound_Tourism.

7. https://www.ncbi.nlm.nih.gov/pmc/articles/PMC6581494/. 